\title{
Dorothea's Marriage Choice in "Middlematch"
}

\author{
Mengyuan Guo \\ English Department \\ North China Eletric Power University (Baoding) \\ Baoding, China
}

\author{
Jie Zhao \\ Science \& Technology College \\ North China Eletric Power University (Baoding) \\ Baoding, China
}

\begin{abstract}
The thesis mainly discusses the various sacrifice complexes in the heroine Dorothea Brooke's personality in Middlemarch written by George Eliot. This paper, using Jung's complex theory to focus on the psychological analysis of the heroine Dorothea, to unfold the formation of sacrifice complex in her character.
\end{abstract}

\section{Keywords-Jung; sacrifice complex; Dorothea}

\section{INTRODUCTION}

Middlemarch, written by which George Eliot, has achieved a unique status as a literary form, which is a great book and one of the few English novels written for the intellectual adult. Multiple plots, with several interlocking sets of characters, is one of the typical feature of this novel: Dorothea - Casaubon - Ladislaw, this line is the most important plots in this novel. The heroine Dorothea Brooke, an ardent, intelligent, idealistic young woman. However, her two marriages look peculiar and incomprehensible, which reflects her psychological trauma of her experiences. This paper focuses on explaining the psychological process of Dorothea, which can explain her marriage choice in a quite different angle. This paper indicates that Dorothea's marriage choice is mainly influnced by sacrifice complex. Complex is Jung's most important early theory to the explaination of the unconscious and its structure. Complex in psych has many different expressional ways, in this paper, the formation of sacrifice complex would be analysized to illustrate how it impules Dorothea to make her decision in Middlemarch.

\section{ANALYSIS OF DOROSIEA'S SACRIFICE COMPLEXES}

\section{A. Sacrifice Complex to Father}

Dorothea is a woman of radiant goodness, a latter-day Saint Theresa, whose two marriages are always misunderstood by Middlemarchers. However, her peculiar actions and choices can be explained by Jung's theory - the complex. Complex means "a particular anxiety or unconscious fear which a person has, as a result of an unpleasant experience that they have had in the past or because they have a low opinion of their own worth, and which influences their behavior.'[1] P485 And according to Jung's explanation: the psyche is a three-dimensional object like the solar system. Egoconsciousness is the earth; it is where we live, at least during our waking hours. The space around the earth is filled with satellites and meteorites, some large, some small. This space is what Jung called the unconscious, and the objects that we first

This research is supported by "the Fundamental Research Funds for the Central Universities of China" (Grant No.13MS124). come across as we venture out into this space are what we called the complexes. The unconscious is populated by complexes. [2]P36

In Jung's theory, the unconscious associations are extremely obscure and hidden. Once the unconscious associations are stimulated, this series of associated material produces a disturbance in consciousness. The unconscious contents, which are responsible for the disturbances of consciousness, are called as complexes, formed by trauma. In the common sense, complexes are generated and formed in a person's personal life history, which is the output of his own specific experience. Dorothea is influenced by those complexes, and the budding period is shown even from her childhood.

In Middlemarch, Dorothea, a girl living in the Victorian Age, lost her father when she was quite young, which caused her imagination about father represents her admiration and devotion to the father image. Loosing a father can cause great psychological damage to a young girl, especially for Dorothea who had to leave home and stay in other families, which leaves her psychological mark through psychic injury or trauma in her personal unconscious. Hence, her psychic injury forms her complexes which are intractable and like frozen memory images of traumatic experiences in her psyche. The father image, as an inner object, are distinguished from the actual father, which are called the father complex or Electra complex and at its core it is an image. In this sense, Dorothea builds a bridge between the psychic image and an external reality, which is buried in her unconscious and with the growth of the individual, more material and images will be added to that complex which can be modified by the later experience, such as the figure of future spouse. As for Dorothea, when she is old enough to find her spouse, the parent figure adds material to her value to choose her husband, especially, the father image takes a great position in her mind, which is someone who father-like who could teach and instruct her and she could take care of, and this image is overlaped with the image when choosing a spouse. In the first chapter of Middlemarch, Dorothea's father complex is unfolded to us: Dorothea, with all her eagerness to know the truths of life, retained very childlike ideas about marriage. She felt sure that she would have accepted the judicious Hooker, if she had been born in time to save him from that wretched mistake he made in matrimony; or John Milton when his blindness had come on; or any of the other great men whose odd habits it would have been glorious piety to endure; but an amiable handsome baronet, who said "Exactly" to her remarks even when she 
expressed uncertainty, - how could he affect her as a lover? The really delightful marriage must be that where your husband was a sort of father, and could teach you even Hebrew, if you wished it.

Dorothea wants to understand the world and to make some contribution, but her abilities are limited by poverty of education and lack of experience which should be guided by her father or a husband who is just like a father and could teach her and direct her in the rest of her life. In her mind, Casaubon, who is twenty seven years old than Dorothea, and her father image begins to mingle together. Besides his appearance is father-like, his profound knowledge also makes her moved. In the meanwhile, she also dreams to be the daughter of Milton, who could help her father image, her husband, to make great achievements. Hooker and John Milton becomes the archetypal image of her husband and marriage is state of higher duties. When Dorothea meets the musty scholar Casaubon she immediately casts him as the great Milton toiling away at his magnum opus, Dorothea's sacrifice complex is budding, and she prepares to devote herself to the feasts of her husband willingly.

\section{B. Sacrifice Complex as a Saint}

John Milton, as the father image in Dorothea's mind, is also the image of great Puritan hero. In Middlematch, Dorothea, having a Puritan heritage, which is traced to an ancestor discernible as a Puritan gentleman who served under Cromwell, is discribed as a spiritual beauty. She is a puritan living in the nineteenth-century, with her penchant for plain garments, searching for a cause to which she might devote her ample heart and earnest soul. Dorothea's idol is St. Theresa and shows her piety which advocates of a strict puritan code of morality, which is so rigorous that it leads her to extreme selfdenial and turn so firmly from the allure of the senses to the purity of the spirit. In her mind, Casaubon, who is a modern St. Augustine, appears to Dorothea as the perfect candidate to fulfill her fantasy of a saint partner whose work will reconcile complete knowledge with devoted piety. In her exalted spiritual nature, to marry Casaubon, she could totally devote herself to something honorable, holy, an great, which is the requirement of her religious faith.

Therefore, Dorothea's sacrifice complex is sitimulated by her Puritan faith which is the heritage of her family, and determined by the historical and social environment. It is also a kind of social culture which modifies the individual's psychic structures significantly.

\section{Sacrifice Complex as a Female}

A person's later experiences can be influenced by family and society, and a individual's life is also shaped by the past through the intimate process of heredity even before the individual's birth. Then the family and society leaves obvious marks upon the individual by imposing inescapable obligations, traditions and restrictions. In this novel, George Eliot sets social background in the early Victorian period, and femininity complex is easy found in women living in Victorian period.

In Victorian Age, women, lack of education and vocation, showing their obedience to their husbands, and playing a domestic role in family, have to regard men as their master, teacher and god unconsciously. Women's status in society indicates that there exists a cultural layer of the unconscious. Because of sharing the similar traumas, women at that time have some common experiences and traditional culture, so they have more or less the same type of complex. Hence, Dorothea's sacrifice complex as a female is a common and collectivecharacter which is quite representative at that time, and she is just one of the victims of the male-dominated society.

In Middlematch, George Eliot ridicules the backwardness and superficiality of attitudes to women, and her irony is heightened through the gentlemen's opinions: Sir James Chettam believes that it is a woman's duty to be cautious and listen to man who know the world better than she does; Lydgate considers women appropriate companions for hours of light relaxation, not for serious pursuits; Caleb Garth tells his daughter Mary that a woman has got to put up with the life her husband makes for her; Borthrop Trumbull asserts that a man whose life is of any value should think of his wife as a nurse; Casaubon expresses a common nineteenth-century view when he speaks of the "characteristic excellence" and "great charm" of woman's nature being its capability of an ardent self-sacrificing affection. With this assumption, it would never occur to a man to think as much about his own qualifications for making a girl happy. As the victim at that time, Dorothea has to turn herself into virtue slaves and put herself in the inferior and weaker postion. As Casaubon's wife, Dorothea admires Casaubon, disregarding herself, and has her great desire to help Casaubon who does great works, so that his burthen might be lighter. Dorothea would like to throw herself, at Casaubon's feet, and kiss his unfashionable shoe-ties as if he were a Protestant Pope. She is not in the least teaching Casaubon to ask if he were good enough for her, but merely asking herself anxiously how she could be good enough for Casaubon. She admits her ignorance and what she thinks is how she would devote herself to Casaubon and become his wife, then she would become wise and strong in his strength and wisdom. She exaggerates Casaubon's power and puts herself on the subordinate position. After marriy him, she becomes more tolerant, for she should be the angel in the house and confine herself to the domestic vocation.

\section{Sacrifice Complex as a Mother}

Dorothea's love towards Will Ladislaw is like a mother's love to her beloved child. After her first marriage, Dorothea is disappointed at Casaubon with time passing by, and she could not have a baby in the unhappy marriage. In a traditional family at that time, a child plays an essential role and is significant to a woman. In fact, every woman has a kind of child complex hidden in her inner mind. As a mother, women are willing to refuse any reward to love and care their baby devotedly. Accordingly, Dorothea's motherhood plays an important role in her second marriage.

Will Ladislaw, as a poor abandoned figure, is not a talented one, and he is self-willed and with an unfortunate life experience. He refuses to choose a specific career because that will put an end to that state of dreamy leisure he calls freedom. Will's position, without money inheritance, sharing the 
awkward financial dependence attracts Dorothea's attention. Dorothea begins to understand him and loves him for his naive thoughts and his weakness, which evoke Dorothea's sympathy and care to him. At the first beginning, her feeling to Will is quite mother-like. In her view, Will is Casaubon's young relative with poor childhood and unfair treatment, so after her marriage, it is common that she should take care of him because Will is just like a boy who is childish, and he needs someone's care and help. Suffering in her unhappy marriage, Dorothea's feeling towards Will deepens with time going on. Therefore, her motherhood inspires hers duty to care about Will and to sacrifice herself to rescue this young man. The language used to describe the relationship between Dorothea and Will is characterized as mother and child, such as the Solomon dividing the child metaphor, derived from the Bible, linked with Mary's grief over Christ's body. Dorothea is figured as Mary, which proves the motherhood of Dorothea, and the bleeding half child which literally means Will who is carried away by the lying woman. In this sense, Will Ladislaw becomes the real "button" that touches her child complex and she would like to show her gentle motherliness. In this sense, Dorothea has passed from wanting to be Casaubon's daughter to wanting to be Will's mother.

\section{CONCLUSION}

In Middlemarch, Dorothea choosing Casaubon and Will as her husbands makes people, even readers puzzled and disappointed. George Eliot concludes that Dorothea's marriage to Will is not an "ideally beautiful act, but a sacrifice". [12 ]P182 Dorothea as the typical representative in Victorian Age, has strong Victorian cast: her sense of duty, her needing to sacrifice, her wanting to quell selfishness, her accepting the importance of being earnest, and those hues exhibit her sacrifice complex in different ways. This paper examines Dorothea Brook's psychological process by Jung's theory of complex, and offers a new angle to anaysize her marriage choices, which is mainly determined by psychological complexes. Dorothea's sacrifice complexes, formed and being formed, are the main factors to shape her thinking and action. By analyzing Dorothea's psychological complexes, this thesis reveals that her marriage choice is comprehensible and reasonable. Whether Dorothea gets a happy marriage or not, her marriages bring her into the real world and bring her from the ideal to the common, which is the moral requirement initiated by George Eliot.

\section{REFERENCES}

[1] Procter, Paul (ed.). "Cambridge International Dictionary of English". Shanghai: Foreign Language Education Press, 2001, pp.485.

[2] Stein, Murray. "Jung's Map of the Soul". Chicago: Open Court, 1987, pp.36.

[3] Leavis, F.R. "The Great Tradition". New York: Doubleday Company, 1954.

[4] Prentis, Barbara. "The Brontë Sisters and George Eliot". London: The Macmillan Press Ltd., 1988.

[5] Adams, Kimberly VanEsveld, "Our Lady of Victorian Feminism". Ohio: Ohio State University Press, 2001.

[6] Eliot, George. "Middlemarch". Kent: Wordsworth Editions Ltd., 1994. 